\title{
Signal and Political Accountability: Environmental Petitions in China
}

\author{
Jiankun LU and Pi-Han TSAI
}

2017

EGC Report No: 2017/11

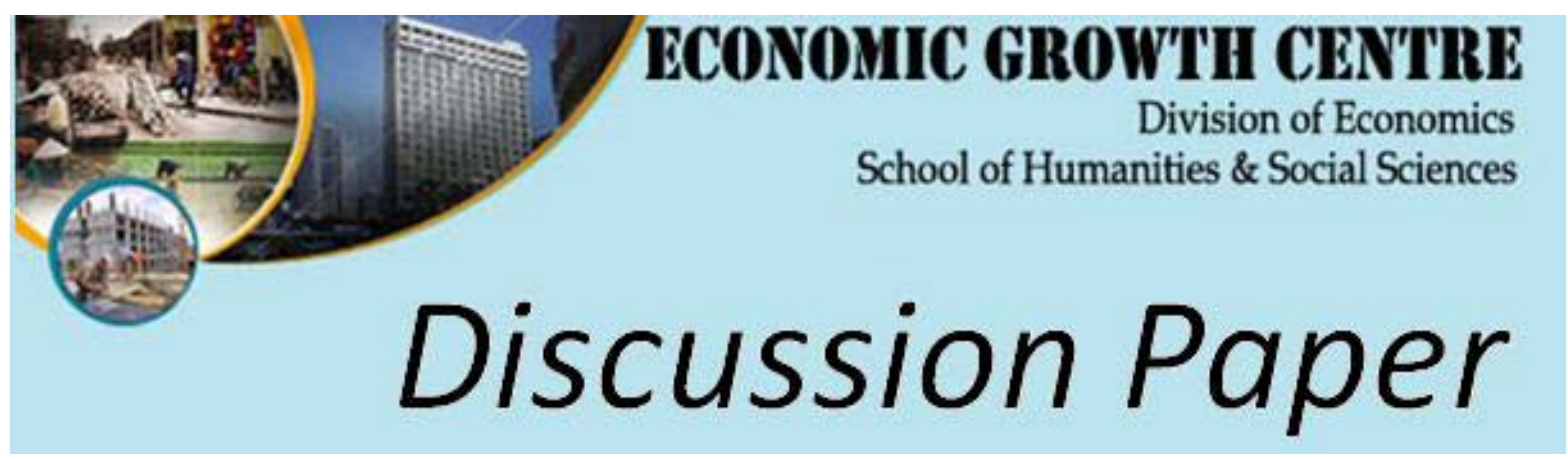


The author(s) bear sole responsibility for this paper.

Views expressed in this paper are those of the author(s) and not necessarily those of the Economic Growth Centre, NTU. 


\title{
Signal and Political Accountability: Environmental Petitions in China
}

\author{
Jiankun $\mathrm{Lu}^{*}$ \\ School of Public Finance and Taxation \\ Zhejiang University of Finance and Economics \\ Pi-Han Tsai ${ }^{\ddagger}$ \\ College of Economics \\ Zhejiang University
}

Current Version: Jun 2017

\begin{abstract}
Vertical accountability in China has long been considered as essentially indirect or informal. This paper provides evidence that direct local accountability may exist to a greater or lesser degree in China under current political institutions. By using provincial environmental petition data, this paper finds that the number of environmental petitions is positively associated with provincial governments' investments in pollution mitigation. The increased petitions serve as a signal to provincial leaders of the possibility of potential social instability. However, since "local" provincial party secretaries are better informed, the signaling effect of the petitions is lessened in these cases.
\end{abstract}

JEL Classification: H11, H70, P26, Q58

Keywords: political signal; political accountability; environmental expenditure

\section{Introduction}

In democratic countries, periodic elections create a relationship of formal accountability between the politicians and the public. To increase their chances of being elected, politicians have an incentive to be responsive to the public and to address their needs. However, in the People's Republic of China, the situation is different. In the absence of both local elections and national political parties, vertical accountability in China has long been considered as essentially indirect or informal (Persson \& Zhuravskaya, 2016). As a singleparty nation, the Chinese Communist Party (CCP) has ultimate power, and it dominates the institutions of the state. Thus, the National People's Congress, as the organ of state power, simply rubber-stamps party decisions (Lawrence \& Martin, 2013). In addition, the procedures for elite recruitment and personnel management are controlled by the CCP; thus, the personnel preferences of the Central Committee are decisive for a local official's political future. Instead of the bottom-up electoral check faced by politicians in democratic countries,

\footnotetext{
* Jiankun Lu is a research fellow at the Zhejiang University of Finance and Economics. Address: Xueyuan Street No. 18, Xiasha Higher Education Park, Hangzhou, China, 310018. Email: lujiankun@zufe.edu.cn.

${ }^{\ddagger}$ Corresponding Author. Pi-Han Tsai is an Assistant Professor at the Zhejiang University. Address: 38 Zheda Rd, Xihu, Hangzhou, Zhejiang, China, 310027. Email: pihant@,zju.edu.cn.
} 
politicians in China confront a range of top-down checks from higher-level party authorities. This cadre management system, created by the center through its system of promotions and demotions, provides sufficient incentive for politicians to adhere to centrally proclaimed goals, and it is the main driving mechanism for shaping politicians' policy directions. In fact, it is widely believed that such powerful career concerns faced by local officials have contributed to the rapid economic growth of China over the last 30 years (Qian \& Xu, 1993; Maskin et al., 2000). ${ }^{1}$

Thus, when compared to politicians in democratic countries, those in China are less accountable to the public in their jurisdictions. However, such top-down checks would become an informal mechanism for political accountability if popularity is one of the important promotion criteria, and included in the political evaluation system. While Chinese leaders' political futures rely less on popular support than those of politicians in a democratic country, they are still compelled to make decisions to avoid widespread social instability (Shih et al., 2005; Tsai, 2016). Hence, in recent years, except for economic growth, to retain political power and establish legitimacy, not only with the Chinese people but also in the international arena, sustainability and social stability have been two very important aspects of the government's evaluation and promotion system (Wang, 2013; Zheng et al., 2014). In fact, maintaining social stability has even become a priority target of local officials, due to the frequency of mass protests that occurred in 2009 (C.E.C.C. Report, 2009). The change in the promotion criteria incentivizes politicians to devote more attention to the public's interests. Zheng et al. (2014) study the association between the intensity of public concern over environmental issues and a mayor's efforts in pollution mitigation. In their work, the intensity of public interest is measured by Internet searches (Google Insight Index) using the key words "environmental pollution," as well as the frequency of pollution-related articles in the city's local newspapers. Their empirical results show that increases in public concern over environmental pollution incentivize urban leaders to tackle pollution issues. By conducting an online field experiment on county government Web forums among Chinese counties, Chen et al. (2016) find that the threat of social instability (e.g., the threat of collective action) and the risk of evoking increased oversight by upper-level government officials increase the responsiveness of local Chinese officials to citizens' requests related to the people's social welfare. They attribute the increased responsiveness to the pressures from below to China's cadre evaluation system. In order to not ruin their careers in the party-state system, local officials must impress their superiors with stable social environments.

Except for the change in promotion criteria, another possible, but imperfect substitute for local accountability is social ties. Compared to an "outside" provincial leader, a "local" provincial leader spends more on education and health care and less on capital construction projects, resulting in a higher provision level of public goods (Persson \& Zhuravskaya, 2016). ${ }^{2}$ Identification comes from variations in provincial leaders' career backgrounds, for example, whether one has had their most important career advancements in the province in

\footnotetext{
${ }^{1}$ Since 1979, the Chinese government has emphasized more quantifiable economic performance standards, implicitly encouraging local officials to develop their local economies.

${ }^{2}$ See also Tsai (2007) and Xu and Yao (2015) regarding the effects of social networks on the provision of public goods in China.
} 
which they govern. However, even though social networks may be an informal institution to incentivize local officials to fund local public goods, their existence does not provide direct evidence of local accountability, a link between citizens' demands and government policy. For instance, an increase in education expenditures shows that local officials care about the development of local education, but the education issue may not be a top priority of citizens. Instead, it may be possible that the residents are mostly troubled by the deteriorating air and water quality, rather than school student-teacher ratios. Thus, this paper explicitly defines local accountability as the association between public concerns and the corresponding actions of local governments.

Barring the above informal channels, this study provides another possible and formal mechanism for political accountability. Namely, this is the Chinese petitioning system (xinfang), which can influence a provincial leader's policy choices. The petitioning system in China is a legitimate mechanism for citizens to express their grievances and to appeal government decisions. Minzner (2006) provides a detailed overview of China's petitioning system and analyzes the state-society interactions that are at its heart. However, China's petitioning system also has a notorious reputation due to its ineffectiveness and low rate of success. It is widely regarded that very few issues are actually solved through this mechanism. For example, according to one 2004 Chinese study, only $0.15 \%$ of cases were solved through the petitioning system (Shao, 2008). Due to its general ineffectiveness and lack of transparency, the country's petitioning system has received little study by either Western or Chinese academics (Minzner, 2006). When it has been examined, most literature focuses solely on the discussion of the drawbacks of the system and provides suggestions for reform (Bruckner, 2008; Shao, 2008). Thus, this paper aims to fill an academic void while contributing to the various strands of economic literature devoted to political accountability in China. To the best of our knowledge, there is no other panel study focusing on political accountability from the perspective of China's petitioning system. Specifically, the purpose of this work is to examine the evidence of vertical accountability in China by investigating the association between the increased petitions and policy outcomes.

Since only the environmental petition data are available, ${ }^{3}$ this paper focuses on increased public concern regarding environmental issues, which we proxy by the number of environmental petitions, as well as the environmental outcomes, which comprise investments in pollution mitigation and environmental performance. By using provincial-level data from

\footnotetext{
${ }^{3}$ Information regarding petitions in China is politically highly sensitive. There is no data on the total number of petitions, nor a record of the different types of petitions. The only petition data available is the record of environmental petitions at the provincial level, which is from the China Environment Yearbook, officially published by the Chinese government. The petition data at the sub-provincial levels, e.g., the prefectural level or the county level, are also not published by the Chinese government, and thus, are not available. Therefore, due to data constraints, this paper focuses only on the environmental petitions at the provincial level. Even though it may not be able to provide a detailed picture on how Chinese officials respond to the petitions at the different administrative levels, or whether Chinese officials treat other kinds of petitions differently from environmental ones, this paper may partially confirms the existence of provincial leaders' political accountability in China, and provides evidence that even in a non-democratic country, politicians still face bottom-up checks in a somewhat similar manner as politicians in democratic countries.
} 
$2003-2013,{ }^{4}$ we find that the number of environmental petitions filed is positively associated with provincial governments' investments in pollution mitigation. Here, however, it needs to be stated that such effects do not always contribute to local "greenness." Even though increased petitions incentivize provincial leaders to augment spending on environmental issues, increased investments are mainly for urban infrastructure facilities. Nevertheless, we find the positive and significant correlation shows that provincial leaders do have an incentive to respond to the public concern over pollution mitigation. Therefore, to a greater or lesser degree, direct local accountability may exist in China under the current political context.

After our initial discussion of the situation in China, we turn our attention to the question of why unelected politicians in the country would care about the public in their jurisdictions if the public does not determine their political advancement. To identify the effect of the petitioning system in China, the second part of the paper focuses on finding the

\footnotetext{
${ }^{4}$ Compared to officials at the sub-provincial levels, officials at the provincial level may have few interactions with local citizens. It is possible that local citizens may be more likely to attribute local environmental problems as responsibility of lower-level governments. In addition, the data at the sub-provincial level could provide more observations and increase variations of the sample. Yet, the problem of data availability (see note 3) restrict our analysis to the provincial level. Nevertheless, we argue that the provincial level data is still useful for getting a general picture of Chinese officials' responsiveness to public concerns via the petitioning system. In China, which has a hierarchical party structure, central and provincial governments have enormous leverage over lower-level governments (Shih et al., 2005). The political dependence of lower-level governments on upperlevel authorities has intensified since the 1994 Tax Sharing Reform (Shen et al., 2012). Thus, the behavior and choices of local officials may correspond with the motives and preferences of upper-level authorities. Wu et al. (2014) find that city-level cadres increased transportation infrastructure investments when their provincial level superiors emphasized such investments. Moreover, most of the important environmental policies and infrastructure projects that can cause serious environmental pollution are determined by the provincial governments. Below are two examples where citizens organized themselves and worked together to get their voices heard by provincial governments. Even though Chinese citizens may have many different organizing strategies to express their views and to deliberate on alternatives, petitions sometimes play a significant role in the interplay between citizens and provincial governments in the context of environmental activism. The first case was the Nu River Dams projects in Yunnan Province. The Yunnan provincial government aimed to improve the local economy by building a hydropower plant to generate and transmit electricity from the west to the east. Sixty-two scientists, journalists, and environmental activists concerned about nature conservation and the danger to the river's ecology signed a petition to preserve the river (Li et al., 2012). Additionally, the Chongqing Green Volunteer Union also collected 15,000 petition signatures opposing the Nu River Dams (Yardley, 2004). As a result, the development was put on hold and the developmental plan was released to the public for discussion. The second case was the Liu Li Tun garbage incineration power plant, which was planned to be an extension of the Liu Li Tun landfill site. Residents were concerned about dioxin and a cancer-causing toxins that can be emitted from burning garbage. They handed their petitions to the Legislative Affairs Office of the Beijing municipal government, asking the government to withdraw approval of the power plant (Li et al., 2012). Eventually, the Liu Li Tun garbage incineration power plant was stopped. Both of these cases show that provincial governments do get involved in the detailed operation of environmental policies, and the filing of petitions is an important tactic for the citizens to voice their concerns.
} 
main mechanism driving the petition effect. We argue that a petition is a multipurpose tool, used not only for governance but also for signaling and for stability preservation. The petitioning system is an open channel for transferring information from an aggrieved populace to upper-level authorities. This apparatus for public discontent resembles a "fire alarm" mechanism of accountability (McCubbins \& Schwartz, 1984). Upper-level authorities use citizens as an oversight mechanism on lower-level officials; this imbues the citizens with the ability to sanction lower-level officials, thus generating responsive actions by lower-level officials to citizens' requests (Chen et al., 2016). An increasing number of petitions provide information about agent performance, exposing the incompetence of principals or potential agency slippage (Weingast, 1984). The petitions help the upper-level authorities to monitor the lower-level officials while simultaneously signaling the local officials about the possibility of an outbreak of social unrest in their jurisdictions, which, in turn, could affect their career advancement. Thus, the top-down checks in the Chinese cadre management system may be the key driver in facilitating the operation of the petitioning system. To investigate this hypothesis, we examine the association between the number of filed petitions and the political turnover of provincial leaders. Here, we find that the likelihood of termination of a provincial leader is correlated significantly and positively with the number of petitions filed in their jurisdiction. However, we also find only a weak and negative correlation between increased petitions and the likelihood of promotion. Therefore, our empirical results suggest that the fear of demotion may be the main driving mechanism for provincial leaders' political accountability. This is because maintaining social stability is a basic criterion for a provincial leader to stay in office.

We further argue that the signaling effect of the petitions may vary across provincial leaders, who have different degrees of local familiarity. Provincial leaders who have strong social networks and connections in their jurisdictions are more likely to be better informed about the risk of escalation regarding the disputes or concerns of their residents. In order to prevent the outbreak of social unrest, if the risk of protest-driven escalation were high, they would take steps to address the problem, even before the petitions are filed. On the other hand, if the risk of protest-driven escalation were low, even after the petitions are filed, they would have less incentive to tackle the issue. However, for provincial leaders who have come from the outside and who have a lower degree of local familiarity, they have less information regarding the concerns of their residents, as well as which disputes may escalate into mass protests. Thus, for them, the filed petitions are a signaling mechanism and a way to gather more information about local concerns. Without sufficient local information, and being naturally risk-averse, a provincial leader would have a greater incentive to respond to the filed petitions in order to prevent the escalation of dissatisfaction into a mass movement. Thus, the third part of this paper tests the signaling effect of petitions on provincial leaders' social networks. Because personal networks grow over time, an official who makes his or her career trajectory within a single province slowly develops local ties to lower-level elites while simultaneously obtaining an affinity for, and a familiarity with, the province he or she is governing (Persson \& Zhuravskaya, 2016). Therefore, compared to officials who make their career trajectories in other provinces, "local" officials looking to move from a low to a high level in the administration or within the party hierarchy are often better informed and have a better network of connections in their jurisdictions. 
Here, it is important to note that the classification of "locals" and "non-locals" in this paper is slightly different from how these terms are used in Persson and Zhuravskaya (2016). Instead of simply categorizing one's career trajectory, we also consider the birthplace of a provincial leader, because, in general, an official will be more familiar with, and have a greater affinity for, the province in which he or she was born. Thus, in this paper, we define "locals" as provincial leaders who were born or rose from low to high positions within the provinces they govern, and "non-locals" as provincial leaders who were born outside the provinces they govern, having had their career advancements elsewhere. ${ }^{5}$ Our empirical results suggest that the variations in provincial leaders' career trajectories and birthplaces lead to varying degrees of political accountability. Compared to locals, non-local provincial leaders are likely to be less informed about the likelihood of potential social instability, and thus, have a greater incentive to respond to the public concern over pollution mitigation. Additionally, in general, we find that non-local provincial leaders are more accountable to the public. The signaling effect of the petitions becomes smaller when a provincial leader's social network and local information increases. Consistent with Persson and Zhuravskaya (2016), our findings indicate that locals have a "home bias" in their budgetary policies, which results in spending more on pollution mitigation.

This paper is organized into six sections. In the following section, Section 2, we review the institution of China's petitioning system and discuss how it relates to the cadre management system. In Section 3, we present our empirical hypotheses and data resources. In Section 4, we discuss our empirical methodology. In Section 5, we review our findings. Finally, in Section 6, we conclude with final remarks.

\section{Review of the Petitioning System in China}

The idea of petitioning - that aggrieved people can bring their complaints to higherlevel authorities and seek justice - is firmly rooted in Chinese history. As early as the twentyfirst century BC, Chinese civilization was defined as a society ruled by man, whereby an intelligent and benevolent emperor was able to punish the wrongdoings of abusive local officials once he realized his citizens were suffering. The purpose of the petitioning system was to monitor local officials, thereby reinforcing the emperor's power and legitimacy (Shao, 2008). In the twentieth century, the CCP followed these historical roots and launched its own petitioning system in 1951 in the form of numerous petitioning bureaus, called Bureaus of Letters and Visits. These bureaus were dispersed throughout all Chinese government organs, including the Party Central Committee, State Council, National People's Congress, procuracies, and courts ( $\mathrm{Li}$ et al., 2012). Using the petitioning system, citizens are able to seek assistance in resolving their grievances and appeal government decisions via either letters or visits to the state or local petitioning bureaus, where officials channel the specific issue to the appropriate department. Thus, the petitioning system is the only legitimate institution for Chinese citizens to express their complaints and objections. The purpose of this paper is to test the effect of increased petitions on policy outcomes.

However, importantly, because petitioning bureaus lack any real power to solve

\footnotetext{
${ }^{5}$ The empirical results do not change significantly when applying Persson and Zhuravskaya's (2016) classification.
} 
practical issues, the petitioning system is notorious for its low rate of success for petitioners. The ineffectiveness of local governments to deal with popular discontent, in turn, puts significant pressure on the state's petitioning bureaus in Beijing (Shao, 2008), as it is common for petitioners to "skip levels" (yueji) of the bureaucratic hierarchy by seeking the intervention of a higher-level party authority to resolve their disputes. In fact, instead of a desperate last resort, petitioning in Beijing has been considered as a fast track to justice (Li et al., 2012). In addition, the occasionally abusive, or even violent tensions at the lower levels of the system have also caused Beijing grave concern.

A series of reforms by the Chinese national government has focused on transforming the deeply flawed petitioning system into a smooth-running bureaucracy. In the $1990 \mathrm{~s}$, the State Council issued the "Regulations of Petition" to provide detailed guidelines to petitioners, and it governs the operation of both the state and local petitioning bureaus. In 2005, a new version of these petitioning regulations was issued, aiming to regularize petitioners and petitioning bureaus further. The effectiveness of officials in handling petitions is linked to their overall performance assessment, and this evaluation is included in the country's performance-based elite promotion system. Thus, the number of petitions, particularly mass petitions, is an important social order target (U.S. Congressional-Executive Commission on China, 2010). The state bureaus assess and rank local governments by the number of "illegal and repeated" petitions filed in Beijing, ${ }^{6}$ and threatens to discipline failing cadres with legal and administrative punishment. This has had the effect of compelling local officials to resolve petitioners' grievances conscientiously and promptly (Shao, 2008). Thus, we hypothesize that top-down checks on Chinese provincial leaders' careers incentivize them to care about the public in a somewhat similar manner as politicians' careers in democratic countries result from bottom-up checks, via the voting booth. In a later section of this paper, we discuss the results of our test of the link between the cadre management system and the performance of officials in handling petitions.

The outwardly stated purpose of the 2005 reform was to assure that petitioners received the same responses from local bureaus as they would from central-level institutions, thereby hoping to prevent petitioners from flocking to the capital to lodge their complaints (Shao, 2008). However, such a structure also encourages officials to be extremely attentive to controlling the expression of social dissatisfaction, and they have an incentive to use a variety of means to suppress petitioners violently (Minzner, 2006). According to a report by Human Rights Watch (2009), in order to prevent petitioners from going to the capital, local governments often suppress petitioners with harsh and violent tactics, ranging from blackmail and extra-legal imprisonment to torture. ${ }^{7}$ Meanwhile, for their part, citizens have learned to use the system as a tool-and sometimes a weapon-to pressure the intervention of authorities into taking action to resolve their disputes, which, in turn, incentivizes petitioners to recast cognizable grievances into larger, better-organized, and more politically mobilized

\footnotetext{
${ }^{6}$ According to the 2005 Petition Regulation, petitioners are only allowed to go to designated offices to submit their petitions, implying that "skipping levels" of bureaucratic hierarchy is illegal. Additionally, if petitioners submit the same petitions repeatedly to different administrative levels of petitioning bureaus, those bureaus have the right to stop handling the petitions.

${ }^{7}$ See Human Rights Watch (2009).
} 
petitions (Minzner, 2006). ${ }^{8}$ Even though the news about petitions is not carried in mass media, local governments are still concerned about the general "social impact" of mass petitions (Chen, 2009). Thus, the threat of a mass petition provides petitioners a better chance to get their voices heard. According to a statistical study by Chen (2009), increased pressure on local officials, which occurs by expanding the size or scope of petitioning activities, has been proven to enhance the probability of a formal response, such as by having officials engage in dialogues with the petitioners or setting up committees to work through the issues, often resulting in meeting part or all of the petitioners' requests. This implies the existence of a signaling effect of the petitions. We explore this aspect in detail in a later section of this work.

Before considering our empirical analyses, the distribution of environmental petitions provides some context on these types of petitions. Figure 1 reports the distribution of the average number of environmental petitions via letters or visits each year by province. Since the act of writing letters is less time-consuming, more convenient, and has nominal transportation costs, Chinese petitioners often prefer letters to visits. The percentage of petitions via letters to the total number of petitions is approximately $83 \%$. In Figure 1, we see that the number of environmental petitions dropped dramatically in 2007, corresponding with the intent of the central government's pre-Olympic efforts. In order to hold the 2008 Beijing Summer Olympic Games and to celebrate the sixtieth anniversary of the founding of the People's Republic of China, the central government increased its level of censorship of unofficial information channels, such as the Internet, as well as carried out widespread surveillance. Chinese officials also exerted some effort in fixing various environmental issues in the showcase areas where public activities would be held (C.E.C.C. Annual Report, 2009). There was thus a decrease in environmental petitions in 2007 , which was perhaps caused by the increased suppression by local governments, as well as specific environmental improvements. In fact, the number of petitions has continued to decline gradually since 2011 . This trend may be attributed to the recent slower economic growth, stemming from lower demand for Chinese exports and a reduction in supply. ${ }^{9}$ In China, public concern over environmental issues is positively correlated with household income (Dong et al., 2011). It is thus likely that during times of economic stagnation, development and growth become the priority for Chinese citizens, instead of environmental pollution, so public distress regarding the environment decreases. The decreasing trend may also be associated with the rapid growth of the use of social media, for example, Weibo, the microblogging service, and WeChat, the widely used mobile communication service in China. According to a 2011 statistical report by the China Internet Network Information Center, Weibo users increased from about 63 million in 2010 to 195 million in the first half of 2011. It was also in 2011 that Wechat was launched, in January of that year. With the rapid rise of social media, information in Chinese society has become both more transparent and more direct. Social media may also

\footnotetext{
${ }^{8}$ In order to handle such "mass incidents," in 2009, the Chinese government issued a series of new rules in order to actively prevent an increase in the number of mass incidents leading to social unrest (C.E.C.C. Report, 2009).

${ }^{9}$ From 2000 to 2010, the growth rate of China's GDP was about 10\%, but it has shrunk since 2011 (World Bank, 2015). However, there is no direct evidence showing a close link between decreased petitioning and economic stagnation.
} 
become a substitute channel for citizens to express their opinions and air their grievances. ${ }^{10}$

Figure 2 reports the distribution of environmental petitions across Chinese provinces in the years 2003-2013. More than one-third of the environmental petitions came from the more developed, coastal, southeastern area of the country; the top four provinces were Guangdong (11.72\%), Jiangsu (8.76\%), Zhejiang (7.84\%), and Shanghai (5.51\%). On the other hand, China's northwestern areas accounted for a smaller percentage of the environmental petitions; here, the fewest four administrative divisions were Tibet $(0.10 \%)$, Qinghai $(0.24 \%)$, Hainan $(0.40 \%)$, and Ningxia $(0.87 \%)$. These results roughly correspond with the argument that there is greater interest in environmental issues among citizens who have higher living standards and who live in areas that have greater mass media openness (Zheng et al., 2014).

\section{Empirical Hypotheses and Data Empirical Hypotheses}

The purpose of this paper is to study the association between petition effects and environmental outcomes to find the driving mechanism of the petitioning system in political accountability. Our four hypotheses are as follows:

H1. An increase in environmental petitions is associated with increased investment for pollution mitigation.

H2. An increase in environmental petitions is associated with local greenness.

H3. The promotion concerns of provincial leaders incentivize them to respond to the public, whereby the likelihood of promotion is negatively correlated to increased petitions, and the probability of termination is positively correlated to increased petitions.

H4. The signaling effect of petitions varies across provincial leaders with different local information, captured by their distinct career trajectories and birthplaces. Compared to local provincial leaders, non-locals are more accountable to the public.

\section{Data Description and Resources}

Both the H1 and $\mathrm{H} 2$ hypotheses explore the associations between the numbers of environmental petitions and the environmental outcomes. (Another dataset is constructed for $\mathrm{H} 3$, and it will be discussed in the later paragraphs.) $\mathrm{H} 4$ further considers the attributes of provincial leaders. Our empirical work uses data from 31 provincial units in China in the years 2003-2013. ${ }^{11}$ The data regarding the number of environmental petitions is drawn from

\footnotetext{
${ }^{10}$ Duncan Hewitt. (2012, August 1st). Weibo brings change to China. BBC News. Retrieved from http://www.bbc.com/news/magazine-18887804

${ }^{11}$ The 31 provincial units include 22 provinces, 4 municipalities, and 5 autonomous regions; Hong Kong and Macau are excluded.
} 
the China Environment Yearbook (Ministry of Environmental Protection, 2004-2014). ${ }^{12}$ The data regarding the environmental expenditures comes from various issues of the China Environmental Statistics (National Bureau of Statistics, 2004-2014). The remainder of the data was gathered from the Provincial Statistical Yearbook for different provinces and years (National Bureau of Statistics, 2004-2014).

For H1, the dependent variables are environmental expenditures, and for H2, the dependent variables are environmental pollutants. The major category of environmental expenditures is the investment in environmental pollution mitigation. ${ }^{13}$ According to China Environmental Statistics, environmental expenditures are the amounts invested in environmental pollution mitigation based on environmental policies and regulation, not only by the provincial government but also by entrepreneurs in the province. Even though such data may not perfectly correspond with provincial governments' fiscal preferences, the entrepreneurial investment still reflects the provincial governments' efforts to mitigate the industrial pollution of entrepreneurs, as well as the provinces' environmental policies; thus, the resulting bias should be minimal. Therefore, we use this data as a proxy to capture the provincial governments' fiscal behaviors on environmental issues. We note that such expenditures incorporate three sub-categories: investment in urban environmental infrastructure facilities, investment in the treatment of industrial pollution sources, and investment in the environment components for three-simultaneity new construction projects. ${ }^{14}$ All of the fiscal data are in current Chinese yuan (100 million), with the figures put in real terms using the General Retail Price Index (with the index for 2003, set equal to 100). The other dependent variable is environmental pollution. Here, four major pollutants are considered: sulfur dioxide $\left(\mathrm{SO}_{2}\right)$ emissions, soot and dust emissions, chemical oxygen demand (COD) in industrial wastewater, and ammonia nitrogen $(\mathrm{NH} 4+-\mathrm{N})$ in industrial wastewater. The first two variables are indicators of air pollution, and the second two are indicators of water pollution. $\mathrm{SO}_{2}$ and $\mathrm{COD}$, both of which are detrimental to human health and land productivity, are two widely used indicators in the literature to measure the impact

\footnotetext{
${ }^{12}$ The data on the number of environmental petitions for each province records the total number of the petitions related to environmental issues received, including letters and visits. The environmental petitions data is collected by the Ministry of Environmental Protection, including the petitions received directly by the petitioning bureaus of local environmental departments and the petitions channeled from the petitioning bureaus of other departments, such as the Public Health Administrative Department and the Civil Affairs Department, but related to environmental issues. The results are robust only when considering the environmental petitions via letters.

${ }^{13}$ Another major source of fiscal data in China is the China Statistical Yearbook. However, the environmental expenditures of provincial governments (i.e, the investment in environmental pollution mitigation by provincial governments solely) were not listed as one of the categories in the book until 2007. In order to obtain the environmental expenditure data over a longer period (2003 and onwards), the data that considers the environmental investment of both provincial governments and entrepreneurs in the province from China Environmental Statistics is applied.

14 The investment in construction projects fulfills the requirement of the "three-simultaneity regulation," meaning that the environmental components of the construction project are completed, their standards live up to stated requirements, and they were implemented starting at the same time as the main project.
} 
of pollution (Jia, 2014). Following $\mathrm{SO}_{2}$, the second foremost air pollutant in China is total suspended particulates (TSP), which is commonly measured by PM10. ${ }^{15}$ In Zheng et al.'s (2014) paper, PM10 is used as a measure of the local quality of life in terms of public health. However, as PM10 data is not available at the provincial level, we use soot and dust data instead, as these components are major sources of PM10. As for NH4+-N, this is one of the major factors threatening the safety of water sources in China (Lin et al., 2009). All of the above environmental data are measured by the ratio of pollutants over production (i.e., emission intensity). To reduce the impact of large values, this paper uses ten thousand tons of emissions of each pollutant per billion Chinese yuan of GDP.

The control variables are both the structural variables and a demographic indicator. The structural variables include GDP per capita and gross regional product by secondary industry. As wealthier provinces have greater budgetary resources than poorer provinces, the GDP per capita is used to control for variations in economic status across the provinces. Moreover, those provinces that rely more on the secondary industry may have greater air and water pollution; thus, there is likely greater pollution mitigation associated with these areas. The demographic indicator is total population. For the regression using environmental expenditures as the dependent variable, we also control for the lagged provincial deficit. The sign of the lagged provincial deficit is expected to be negative.

The H4 hypothesis further considers the career trajectories and birthplaces of provincial leaders. ${ }^{16}$ By following Persson and Zhuravskaya (2016), for each provincial leader, we record whether, prior to their current position, that leader: (1) worked in the same province, (2) worked in a different province, or (3) worked with the central party organs or in the central government. Yet, as discussed above, in our research, the distinction between locals and non-locals is slightly different from that of Persson and Zhuravskaya (2016). In addition to their career path, we also consider a provincial party secretary's birthplace. The local variable is an indicator that equals 1 if a provincial leader rose from a low to a high position in the province he or she governs or if he or she was born in the same province; it equals 0 if a provincial leader made significant career advancements in another province and was not born in the province in which he or she governs. The descriptive statistics of these variables are found in Table 1. From Table 1, we see that about one-third of the province*year observations in our sample have local provincial leaders. On average, local provincial leaders invest more in pollution mitigation, and their provinces suffer less pollution. Yet, the number of environmental petitions is higher in the provinces governed by local provincial leaders.

As for the H3 hypothesis, we construct another dataset of provincial leaders by province and year; it contains information regarding both provincial party secretaries and

\footnotetext{
${ }^{15}$ TSP measures the mass concentration of particles in the air. Within TSP, PM10 refers to atmospheric particles with a diameter of $10 \mu \mathrm{m}$ or less.

${ }^{16}$ Instead of provincial governors, we focus on the provincial party secretaries' fiscal behaviors, as they are the de facto persons in charge within each province. The power to control provincial budgets is in the hands of provincial party secretaries.
} 
provincial governors from 2003 to $2013 .{ }^{17}$ The information on each provincial leader includes their age, education, birthplace, previous working experience prior to their current position, career trajectory, and economic performance in their jurisdiction. The data tracks not only their prior job experience but also the nature of the political turnover (i.e., promotions, lateral moves, demotions, or retirement), as well as each individual's position after a turnover. The main dependent variable of $\mathrm{H} 3$ is the promotion and termination variable. ${ }^{18}$ The definitions of a promotion and a termination, including retirement and demotions, follow Li and Zhou (2005). To avoid omitted variables bias, some control variables are considered here. Under the cadre management system, economic performance is one of the important criteria to determine one's political future. The likelihood of a provincial leader's promotion is correlated to the economic performance in his or her jurisdiction (Li \& Zhou, 2005). Thus, each year's GDP in each province is controlled. In addition, each provincial leader's personal characteristics, including their age and education, are also controlled. Higher authorities prefer younger and more educated leaders.

\section{Empirical Methodology \\ Petition Effects on Environmental Outcomes}

The first estimated model, intended to test H1, is as follows:

Spending $_{i t}=\alpha_{i}+\beta_{1}$ Spending $_{i t-1}+\beta_{2}$ Petition $_{i t}+\beta_{3}$ Petition $_{i t-1}+\beta_{4} X_{i t}+\delta_{t}+\varepsilon_{i t}$.

The dependent variable is the fiscal expenditure in a particular category in province $i$ in year t, measured in hundred millions of 2003 Chinese yuan. The lagged dependent variable appears on the right-hand side due to the persistence of fiscal expenditure. The independent variable we are interested in - the petition variable - captures the effect of public concern over pollution on fiscal expenditures in both the current period and the lagged period. $X_{i t}$ is a vector of the control variables, including GDP per capita, gross regional product by

\footnotetext{
${ }^{17}$ Since both provincial party secretaries and provincial governors are assigned and appointed by the central government, their political turnover is associated with their performance, as determined by the CCP's Central Committee. Thus, the dataset of political turnover of provincial leaders includes both positions. The dataset has been complied by the authors. The data on the provincial leaders' personal information come mainly from the databases of two websites: renminwang (http://ldzl.people.com.cn) and xinhuawang (http://www.xinhuanet.com/politics/rs.htm). The data on the economic performance of provincial leaders' jurisdictions are from various issues of the China Statistical Yearbook from 2004 to 2014.

${ }^{18}$ The promotion variable is an indicator variable that equals 1 if a provincial leader is promoted; otherwise it is 0 . The termination variable is an indicator variable that equals 1 if a provincial leader is either demoted or retired; otherwise it is 0 .
} 
secondary industry, total population, and lagged provincial deficit. ${ }^{19}$ Additionally, the regression includes year fixed effects $\left(\delta_{t}\right)$ and province fixed effects $\left(\alpha_{i}\right) . \varepsilon_{i t}$ is a disturbance term that is likely to be correlated across years.

In the above baseline model, there are two potential problems that may bias the results when applying a fixed effect estimator. The first potential bias is a simultaneity problem, whereby the petition variable in the current period may be endogenous. On the one hand, an increase in public concern over pollution may amplify a provincial leader's incentive to shift government spending toward environmental protection, resulting in better environmental performance. On the other hand, a province with lower environmental expenditure and greater pollution may lead to an increase in resident complaints, growing the number of environmental petitions. The second potential bias is the possible correlation between the dependent variable and its lag in the first estimated model. This especially would be the case with the Fisher-type test, where the lag lengths are selected using the Akaike information criteria, suggesting that the panels of all the series of fiscal expenditure variables contain unit roots. The time series processes of these variables are non-stationary, and the bias of the fixed effect may be sizable. Thus, to avoid these two potential problems, we apply the generalized method of moments (GMM) estimator, proposed by Arellano and Bond (1991) for dynamic panel data models. ${ }^{20}$ Instead of using longer lags of the dependent variable to instrument for the difference, ${ }^{21}$ the number of social groups is also applied as an additional instrumental variable. In fact, we find that the number of officially registered social organizations in each province - the social-group variable ${ }^{22}$ - is closely related to the number of petitions in China;

\footnotetext{
${ }^{19}$ As suggested by an anonymous reviewer of this work, we consider the environmental pollution variable (the variables we applied in $\mathrm{H} 2$, either the lagged environmental pollution or the current environmental pollution) as an additional explanatory variable, because environmental expenditures may be associated with the fundamental nature of the pollution, which the government may observe directly and partially without knowing about an increased number of petitions. While including the pollution variable as an additional control variable, the magnitude and significance of the coefficients are consistent with the baseline regression model (shown in Table 3), demonstrating the robustness of the results and confirming the existence of the signaling effect. The regression results are not reported here, but are available from the authors upon request.

${ }^{20}$ Firstly, we take the first differences. Secondly, we apply an instrumental variables approach by using two lags of the dependent variable (spending ${ }_{i-2}$ and spending $_{i-3}$ ) as instruments for the difference ( $\Delta$ spending $_{i-1}$ ), thus eliminating the resulting inconsistency.

${ }^{21}$ The results are robust when applying the longer lags of the dependent variables, but the longer instrument list results in a weak Hansen test for some specifications. Thus, to avoid the overfitting of the instrumented variables, we apply only two lags of the dependent variables.

${ }^{22}$ The data for the social-group variable was collected from various issues of the China Civil Affairs'Statistical Yearbook (Ministry of Civil Affairs of China). It is important to note that the social groups here only include the social organizations that are officially registered with the sub-provincial or provincial governments each year. Different from a more expansive definition of social organizations, which may include all kinds of citizen-run organizations, officially registered social groups must go through a political vetting process because they need to get approval from, and are supervised by, respective government departments. So, they have no incentive to act against the government or the party. Instead of engaging in contentious politics, most of these groups aim at educating the public and changing citizens' behavior (Brettell, 2003).
} 
the first-stage regression is reported in Table 2. In Table 2, we see that the number of social groups is negatively correlated with the number of environmental petitions. Even though the number of social organizations increases over time, they are developed within a highly restrictive legislative and organizational framework that ensures party control and monitoring (Saich, 2000). The registration process and the government's regulations hamper bottom-up initiatives and favor social groups with close party and government ties. Different from politically active social groups in democratic countries, which may be able to affect government policy by propaganda and lobbying, the purpose of social groups in China is to thwart and limit the possibility of political-ideological disobedience that may arise, as well as to facilitate the implementation of state policies and bridge the gap between the government and the people. Thus, we observe that a greater number of registered social groups lead to a decrease in the number of environmental petitions. We also argue that using the social-group variable as an instrument fulfills the requirement of the exclusion restriction. Institutionally, there is no well-established institutional framework for social groups to participate in the policy process (Tan \& Zhan, 2008). In addition, the social groups representing the interests against the party are unlikely to be registered in the next term, so they tend to maintain good relationships with the party and the government, and have no incentive to violate the government's policies. ${ }^{23}$ Thus, the social-group variable is a valid instrumental variable. A description of the detailed registration process and the development of social groups in China is found in Saich (2000).

The second estimated model, aimed to test the $\mathrm{H} 2$ hypothesis, studies the association between increased petitions and environmental pollution.

Pollution $_{i t}=\gamma_{i}+\theta_{1}$ Petition $_{i t}+\theta_{2}$ Petition $_{i t-1}+\theta_{3} Z_{i t}+\eta_{t}+\mu_{i t}$.

Here, the dependent variables in Equation (1) are replaced by pollution variables. The petition variables capture the effect of the public concern over environmental pollution. $Z_{i t}$ includes the GDP per capita, gross regional product by secondary industry, and total population. In addition, both the year fixed effects $\left(\eta_{t}\right)$ and the province fixed effects $\left(\gamma_{i}\right)$ are controlled. Since the petition variable is potentially endogenous, we apply an instrumental variable approach, whereby the social-group variable is used as an instrumental variable.

We then estimate the $\mathrm{H} 4$ hypothesis to test if the petition effect varies across provincial leaders with different career trajectories and birthplaces. Since local provincial leaders who have more connections to local elites are better informed about the likelihood of social instability, they rely less on the signaling effect of petitions. Therefore, we hypothesize that compared to non-local provincial leaders, locals are less responsive to the public's filed petitions. To test this hypothesis, we add both a local dummy and the interaction term between the local dummy variable and the petition variable to Equation (1); note that the

\footnotetext{
${ }^{23}$ Tan and Zhan (2008) interview 31 environmental NGO officials. (Due to the strict registration requirements, among the 28 environmental NGOs interviewed, only 10 were officially registered.) They find that in China, the key mission of civic environmental NGOs is environmental education. Environmental NGOs in China play a very limited role in influencing government policies, and they prefer not to involve political means, like collective protests or engaging in politically activities (Tan \& Zhan, 2008).
} 
lagged petition variable is removed. ${ }^{24}$ The petition effects are computed by adding the petition coefficient to the local-petition interaction coefficient. By applying the test of general linear restriction, the petition effect on the spending of a local provincial leader and a nonlocal provincial leader are computed respectively.

\section{Provincial Leaders' Career Concerns}

If the number of petitions - the proxy for social instability-is included in the promotion evaluation system, provincial leaders would have the incentive to respond to public discontent. In this case, career concerns may be the driving mechanism of political accountability in a province. Thus, the third estimated model, intended to test the H3 hypothesis, focuses on the association between the number of petitions and the likelihood of a promotion or termination of a provincial leader:

Promotion $_{i t}=\pi_{i}+\rho_{1}$ Petition $_{i t}+\rho_{2}$ Petitioni $_{t-1} Y_{i t}+\lambda_{t}+\kappa_{i t}$.

The dependent variables in Equation (3) are either the promotion dummy or the termination dummy of a provincial leader, indicating whether the provincial leader of province $i$ is promoted or terminated in year $t . Y_{i t}$ includes the GDP per capita, as well as the provincial leader's age and education level. In addition, the year fixed effects $\left(\lambda_{t}\right)$ and the province fixed effects $\left(\pi_{i}\right)$ are controlled. Here, we apply a probit model.

\section{Empirical Results}

\section{Petition Effects on Environmental Outcomes}

Table 3 shows the results of the regressions using environmental expenditures as dependent variables. Column 2 of Table 3 demonstrates that the number of environmental petitions is positively associated with the local governments' investments in pollution mitigation.

\footnotetext{
${ }^{24}$ As suggested by an anonymous reviewer of this paper, to consider the possibility that local and non-local provincial leaders may put different weights on the pollution levels, we added the lagged environmental pollution variable and the interaction term between the local dummy variable and the lagged environmental pollution variable as additional explanatory variables to Equation (1); note that the lagged petition variable is removed. While including the above two pollution variables, the magnitude and significance of the coefficients of petition $(t)$ and the interaction term between the local dummy and petition $(t)$ are consistent with Table 6; only the coefficients of the local dummy become less significant. However, the insignificance of the pollution variables shows that the fundamental nature of pollution may not play an important role in determining government spending, therefore we do not observe a significant difference between local and non-local fiscal behaviors relative to pollution levels. It is possible that this is because provincial leaders care far more about social stability, which determines their political futures, than pollution levels. Thus, the different fiscal behaviors of locals and non-locals result from their information asymmetry about the risk of escalation in particular disputes or the concerns of local residents, and not about pollution levels. Secondly, according to Persson and Zhuravskaya (2016), compared to non-local provincial leaders, local provincial leaders have greater incentives to cater to low-level elites, who have helped them rise to power, and such an effect contributes to the "homebias" budgetary policies of the local officials. Thus, the higher environmental spending of local officials may not correspond with the needs of the public, so that spending may not be associated with actual pollution levels. The regression results are not reported here, but are available from the authors upon request.
} 
However, such effects mainly come from the provincial governments' investment in urban environmental infrastructure facilities, and not from the treatment of industrial pollution sources or environment components for the three-simultaneity new construction projects. Furthermore, Column 3 of Table 3 shows that provincial leaders may have incentives to shift the investments in industrial pollution projects to urban environmental projects, albeit these investment amounts are minimal. The geographic distribution of the number of environmental petitions (Figure 2) provides a possible explanation of such a bias toward urban areas: citizens living in regions with greater media openness and better economic performance have stronger demands for environmental quality, as well as greater public concern over pollution mitigation, so that the number of petitions is higher in the more developed and urbanized provinces, associated with higher environmental investment. It is also possible that such uneven investment comes from the bias of provincial leaders. According to Wang et al. (2008), due to the sophistication of urban businesses, local governments are more likely to have closer ties and to collude more with rural enterprises, thus making environmental regulations weaker in rural areas. Different characteristics of enterprises result in different systems of governance and may also bias provincial leaders' environmental efforts, potentially leading to the imbalanced investment levels in pollution mitigation between urban and rural areas. In sum, the positive correlation between the number of petitions and the increased environmental investment suggests that Chinese citizens' rising demands for a clean environment do contribute to local politicians' accountability in environmental efforts. Thus, direct local accountability may exist in China under current political institutions.

Table 4 reports the results of the regression using environmental pollutants as the dependent variables. All the coefficients of petition(t) and petition(t-1) in Table 4 are insignificant, showing that an increase in public concern over pollution is not correlated with the improvement of the environment. This may be attributed to the ineffectiveness of the provincial leaders to respond to the petitions. The increased petitions may, more or less, reflect the degree of pollution mitigation difficulty; thus, more petitions suggest the severity of the fundamental environmental problems, so we do not observe any corresponding environmental improvements. It is true that the environmental governance and development is a long-term project. A pollution problem usually leads to negative externalities that spill over across regions, requiring not only the effort of the central government but also the negotiation and collaboration of local governments. Without an interjurisdictional negotiation mechanism and regional collaboration, free riding is inevitable (Kahn et al., 2015) and local greenness efforts are less likely. Therefore, even though we observe that an increase in public concern incentivizes provincial leaders to boost spending in pollution mitigation, this does not contribute to local greenness. The empirical results also imply that investment in pollution mitigation may not be allocated effectively. An increase in investment may be just one of the mechanisms that local governments' use to maintain stability, which is sometimes known as "buying stability"- literally meaning paying cash for peace (Lee \& Zhang, 2013). The easiest and fastest tactic for local officials to pacify aggrieved petitioners is to increase environmental expenditures, positively demonstrating the efforts of local governments. According to Lee and Zhang (2013), buying stability takes not only the form of cash 
payments but also the form of local governments paying for services and utilities when these are the subjects of the public's discontent. The primary purpose of buying stability is to pacify aggrieved Chinese citizens and depoliticize social unrest, helping to resolve people's legitimate and rational appeals under the leadership of the CCP (Fewsmith, 2012; Lee \& Zhang, 2013). Thus, increased investment in pollution mitigation is a way for local governments to absorb dissent, rather than to solve practical environmental issues. Consequently, increased petitions are only associated with increased environmental public spending, but not related to the actual improvement of environmental conditions.

\section{Provincial Leaders' Career Concerns}

Table 5 reports the probit regression results estimating the effect of petitions on the turnover of provincial leaders. Columns 2 through 4 of Table 5 show that increased petitions in the current period are associated with the likelihood that a provincial leader's termination will occur in the next period. All the coefficients of Petition $t_{t-1}$ are positive and statistically significant. The immediate effect of the petitions on the termination of politicians is ambiguous; as can be seen, only Column 3 shows a significant effect. Further calculations of the marginal effects based on Column 2 demonstrate that a one-unit (per one thousand petitions) increase in the Petition $_{t-1}$ variable is likely to enhance the possibility of a provincial leader's termination by $0.4 \%$. This result is consistent with common intuition, as it would be rare to see a Chinese provincial leader leave his or her office due only to sporadic citizen complaints. However, the intensity of public discontent may have an influential effect on the official's career. After all, provincial leaders are still threatened by mass public petitions. Moreover, both the variables age and $\operatorname{logg} d p$ show the expected sign, as previously mentioned. In Columns 5 through 7 of Table 5, we replace the dependent variable by the promotion dummy variable. With further calculations, Column 5 of Table 5 suggests that a one-unit (per one thousand petitions) increase in the Petition $_{t-1}$ variable is likely to decrease a provincial leader's chances of promotion by $0.3 \%$. Yet, the coefficients become less significant once different specifications are considered (Columns 6 and 7), and where all coefficients of Petition $_{t}$ are statistically insignificant (Columns 5 through 7).

The empirical results demonstrate that an increase in petitions is highly correlated with the odds of a provincial leader's termination, rather than their likelihood of promotion. The upper-level authority would sooner punish a provincial leader who fails to maintain social stability than reward a successful one. Different from the criteria of economic prosperity and local greenness, informing the upper-level authority about a provincial leader's administrative ability, the number public petitions-as a proxy for social instability - signals that provincial leader's ineffectiveness. According to a survey on Chinese bureaucrats conducted in 2011, official respondents ranked citizens' petitions equally detrimental for their careers as negative media coverage (Distelhorst, 2012). This confirms our finding that there is an association between the number of petitions and an official's career prospects.

\section{Petition Effects Across the Localness of Provincial Leaders}

Table 6 reports the effects of petitions while considering provincial leaders' different career 
trajectories and birthplaces. From the top panel of Table 6, all of the coefficients of Petition show nearly the same signs and power as the estimated results found in Table 1 (only that in Column 4 becomes less significant), thus verifying the robustness of our results. The researchers Persson and Zhuravskaya (2016) find that a local provincial leader has a "home bias," so that that leader will prefer to spend more on local public goods. The same logic applies in the following situation: compared to non-locals, local provincial leaders have a greater incentive to spend more on pollution mitigation. The Local coefficient in Columns 2 and 3 of Table 6 are statistically significant at the 5\% level. However, as mentioned previously in this paper, we define local accountability as the direct link between public concern and the local government's corresponding behavior. The significance of the Local coefficient shows that local provincial leaders care more about environmental issues compared to non-local provincial leaders, but it does not mean that they are more accountable to the public. The descriptive statistics from Table 1 also illustrate that, on average, the number of filed petitions is even higher for provinces governed by local provincial leaders, implying that increased environmental expenditures may not correspond with the needs of the public. For example, it is possible that local provincial leaders have more connections to local elites, so that an increase in environmental investment in pollution mitigation may be solely designed to reward local elites by tackling the environmental problems of their specific working and living areas. Here, the increased environmental spending would only be beneficial to the local elites, rather than the general public. Thus, if we focus on the responsiveness of provincial leaders, we still need to look at the coefficients of the interaction term of the local-petition variables. A provincial leader is accountable to the public only if there is a direct connection between the increase in petitions and an increase in environmental spending. The coefficients of the local-petition variables in Columns 2 and 3 show both negative and significant effects, implying less responsiveness by local provincial leaders. In addition, we apply a test of general linear restriction, and these results are reported in the bottom panel of Table 6 . Columns 1 through 4 of the bottom panel suggest that compared to local provincial leaders, non-local provincial leaders have a greater incentive to increase spending on pollution mitigation, whereby they would be more responsive to the general public. The empirical results of Table 6 confirm our hypothesis that the signaling effect varies across provincial leaders' characteristics. Provincial leaders who are better informed and have a better network of connections in their jurisdictions have more information about potential social unrest. For this reason, they have less incentive to respond to citizen petitions and are less accountable to the public.

\section{Conclusion}

Political accountability is about making local governments more responsive to the felt needs of their citizens. In democratic countries, electoral mechanisms allow ways for citizens to hold local officials accountable. Yet, formal institutions of political accountability are often weak in developing countries (Bardhan, 2002; Tsai, 2007). This is also the case in some developed countries when there is an absence of national political parties and local elections. This is the case of China. Most research literature in this domain focuses on informal political systems, such as local ties (Tsai, 2007; Persson \& Zhuravskaya, 2016; Xu and Yao, 2015) and the effects of mass media (Zheng et al., 2014; Chen et al., 2016). This paper innovatively 
uses environmental petitions data as a measurement to capture the intensity of public concern over environmental issues, contributing to the literature by analyzing other possible mechanisms, including political accountability and China's petitioning system, even though the petitioning system has been widely criticized for its ineffectiveness and low rate of success.

Since social stability is an important target of China's central government, this paper argues that local Chinese officials' career concerns may be one of the main driving forces of provincial accountability, incentivizing provincial leaders to respond to citizens' requests. The empirical results discussed above provide evidence that increased petitions affect provincial governments' decisions in China. As it pertains to environmental issues, we find that provincial governments respond to public concern when they fear the outbreak of social unrest, and they do so, in part, by increasing their investments in pollution mitigation measures. Furthermore, we argue that a greater number of petitions serve as a signal to provincial leaders of the likelihood of potential social instability. Less informed provincial leaders rely more on the signaling effect of the petitions to acquire local information, helping them prevent potential outbreaks of social unrest, and creating a situation where they are more responsive to the public. Thus, the signaling effect varies across provincial leaders, each having different degrees of local familiarity. To verify this hypothesis, we distinguish between local and non-local provincial leaders based on their career trajectories and birthplaces. We find that, compared to local provincial leaders, non-local leaders have a greater incentive to respond to the filed petitions and that they are more accountable to the public.

While concluding the empirical results, however, it is necessary to discuss the potential limitation of the data. Since the environmental petitions data consists of petitions related to environmental issues received by different departments (see note 12), the petition complaints vary widely, ranging from a noisy construction site to a polluted river because of a manufacturing enterprise. Thus, the government's reactions to these complaints can take many different forms. According to Chen (2009), government responses to petitions may include engaging in a dialogue with the petitioners, setting up a special team or meeting to discuss the issue, or providing government spending to tackle the problem. Therefore, provincial environmental expenditure data may only partially capture local officials' responses to the public concerns. That said, this data is the most quantifiable, and the only available, data on governmental responses that we can obtain.

In sum, the findings here provide evidence of political accountability at the provincial level under the current Chinese context. However, the response efforts and increases in spending are just two means for local governments to help pacify citizens. After all, two of the chief purposes of local governments is to reduce public complaints and maintain stability, but not to achieve substantive policy objectives or results. Increased public concern about environmental issues-deduced by a greater number of petitions-increases the government's environmental spending, but we find that it has no real effect on the improvement of the environment. In other words, local officials still need a vested interest to be motivated to resolve practical local issues, rather than simply responding to the public (and the central government) in a superficial manner. The significant improvement of the environment requires a strong collaborative effort between the central and local governments, 
as well as the proper infrastructure to deal with interjurisdictional negotiations. Without regional collaboration and central-local cooperation, local greenness efforts are far less likely.

\section{References:}

Arellano, Manue, and Stephen Bond. 1991. "Some Tests of Specification for Panel Data: Monte Carlo Evidence and an Application to Employment Equations." The Review of Economic Studies, 58, 227-297.

Bardhan, Pranab. 2002. "Decentralization of Governance and Development." Journal of Economic Perspectives, 16(4), 185-205.

Brettell, Anna. 2003. "The Politics of Public Participation and the Emergence of Environmental Proto-movements in China." Dissertation Abstracts International, Volume: 64-09, Section: A. page: 3455.; Chair: Margaret Pearson.

Bruckner, Matthew. 2008. "The Paradox of Social Instability in China and the Role of the Xinfang System." Cambridge Student Law Review, 92-116.

Chen, Jidong, Jennifer Pan and Yiqing Xu. 2016. "Sources of Authoritarian Responsiveness:

A Field Experiment in China." American Journal of Political Science, 60(2), 383-400.

Chen, Xi. 2009. "The Power of 'Troublemaking': Protest Tactics and Their Efficacy in China." Comparative Politics 41(4), 451-471.

China Internet Network Information Center. 2011. 28th Statistical Report on Internet Development in China. Available at SSRN: http://www.cnnic.net.cn/hlwfzyj/ hlwxzbg/hlwtjbg/201206/t20120612_26719.htm (Access on Apr. 26, 2016)

Distelhorst, Greg. 2012. "Publicity-driven Accountability in China: Qualitative and Experimental Evidence." MIT Political Science Department Research Paper Working Paper. 2012-24. Available at SSRN: http://ssrn.com/abstract=2153057 (Access on Feb. 29, 2016)

Dong, Yanli, Masanobu Ishikawa, Xianbing Liu, and Shigeyuki Hamori. 2011. "The Determinants of Citizen Complaints on Environmental Pollution: an Empirical Study from China." Journal of Cleaner Production, 19, 1306-1314.

Fewsmith, Joseph. 2012. "Social Management as a Way of Coping with Heightened Social Tension.” China Leadership Monitor, no. 36, 1-8.

Human Rights Watch Report. 2009. "An Alleyway in Hell: China's Abusive 'Black Jails'." November 2009.

Kahn, Matthew, Pei Li and Daxuan Zhao. 2015. "Water Pollution Progress at Borders: the Role of Changes in China's Political Promotion Incentives." American Economic Journal: Economic Policy, 7(4), 223-242.

Lawrence, Susan and Michael Martin. 2013. "Understanding China's Political System." Congressional Research Service Report for Congress (R41007; Mar. 20, 2013). Accessed May 19, 2013.

Lee, Ching Kwan, and Younghong Zhang. 2013. "The Power of Instability: Unraveling the Microfoundations of Bargained Authoritarianism in China." American Journal of Sociology, 118(6), 1475-1508.

Li, Lianjiang, Mingxing Liu and Kevin O'Brien. 2012. "Petitioning Beijing: The High Tide of 2003-2006." China Quarterly 210, 313-334.

Li, Wanxin, Jieyan Liu, and Duoduo Li. 2012. "Getting Their Voices Heard: Three Cases of Public Participation in Environmental Protection in China." Journal of Environmental 
Management, 98, 65-72.

Lin, Li, Songhu Yuan, Jing Chen, Zuqun Xu, and Xiaohua Lu. 2009. "Removal of Ammonia Nitrogen in Wastewater by Microwave Radiation." Journal of Hazardous Materials, 161, 1063-1068.

Jia, Ruixue. 2014. "Pollution for Promotion." Working Paper.

Maskin, Eric, Yingyi Qian, and Chenggang Xu. 2000. "Incentives, Information, and Organizational Form.” Review of Economic Studies, 67(2), 359-378.

McCubbins, Mathew, and Thomas Schwartz. 1984. "Congressional Oversight Overlooked: Police Patrols versus Fire Alarms." American Journal of Political Science, 28(1), 165 179.

Ministry of Civil Affairs of China. 2004-2014. China Civil Affairs' Statistical Yearbook. Beijing: China Statistics Press.

Ministry of Environmental Protection. 2004-2014. China Environment Yearbook. Beijing: China Environmental Yearbook Society.

Minzner, F. Carl. 2006. "Xinfang: An Alternative to Formal Chinese Legal Institutions." Stanford Journal of International Law, 42(1), 103-179.

National Bureau of Statistics. 2004-2014. China Environmental Statistics. Beijing: Chinese Statistics Press.

National Bureau of Statistics. 2004-2014. Provincial Statistical Yearbook. Beijing: Chinese Statistics Press.

Persson, Petra and Ekaterina Zhuravskaya. 2016. "The Limits of Career Concerns in Federalism: Evidence from China." Journal of the European Economic Association, 14(2): 338-374.

Qian, Yingyi and Chenggang Xu. 1993. "Why China's Economic Reforms Differ: The Mform Hierarchy and Entry/Expansion of the Non-state Sector." Economics of Transitions, $1(2), 135-170$.

Saich, Tony. 2000. "Negotiating the State: the Development of Social Organizations in China." China Quarterly, 161, 124-141.

Shao, Qin. 2008. "Bridge Under Water: The Dilemma of the Chinese Petition System," China Currents, 7(1).

Shen, Chunli, Jin, Jing, Zho, Heng-fu. 2012. "Fiscal Decentralization in China: History, Impact, Challenges and Next Steps." Annals of Economics and Finance 13-1: 1-51.

Shih, Victor, Mingxing Liu, Qi Zhang. 2005. "Eating Budget: Determining Fiscal Transfers under Predatory Fiscal Federalism.” FED Working Papers Series: FE20050009.

Tang, Shui-Yan and Xueyong Zhan. 2008. "Civic Environmental NGOs, Civil Society, and Democratisation in China." The Journal of Development Studies, 44(3), 425-448.

Tsai, Lily. 2007. "Solidary Groups, Informal Accountability, and Local Public Goods Provision in Rural China." American Political Science Review, 101(2), 355-372.

Tsai, Pi-Han. 2016. "Fiscal Incentives and Political Budget Cycles in China," International Tax and Public Finance, Forthcoming. DOI: 10.1007/s10797-016-9392-5

United States. Congressional-Executive Commission on China. 2009 Annual Report. One Hundred Eleventh Congress, First Session, October 10, 2009. Available via the World Wide Web: http://www.cecc.gov. 
United States. Congressional-Executive Commission on China. 2010. "China's Citizen Complaint System: Prospects for Accountability : Roundtable Before the CongressionalExecutive Commission On China." One Hundred Eleventh Congress, First Session, December 4, 2009. Washington: U.S. G.P.O..

Wang, Mark, Michael Webber, Brian Finlayson, and Jon Barnett. 2008. "Rural Industries and Water Pollution in China." Journal of Environmental Management, 86, 648-659.

Wang, Alex. 2013. "The Search for Sustainable Legitimacy: Environmental Law and Bureaucracy in China." Harvard Environmental Law Review, 37(2), 365-440.

Weingast, Barry. 1984. "The Congressional-bureaucratic System: a Principal Agent Perspective (with Applications to the SEC)." Public Choice, 44(1), 147-191.

World Bank. 2015. "East Asia and Pacific". Available at: http://www.worldbank.org/en/publication/global-economic-prospects/regionaloutlooks/Global-Economic-Prospects-June-2015-East-Asia-and-Pacificanalysis\#5 (Access on Mar. 24, 2016)

Wu, Jing, Yongheng Deng, Jun Huang, Randall Morck, and Bernard Yeung. 2014. "Incentives and Outcomes: China's Environmental Policy." Capitalism and Society, 9(1), Article 2.

$\mathrm{Xu}$, Yiqing and Yang Yao. 2015. "Informal Institutions, Collective Action, and Public Investment in Rural China." American Political Science Association, 109(2), 371-391.

Yardley, Jim. 2004. "Dam Building Threatens China's 'Grand Canyon'." The New York Times 10 March.

Zheng, Siqi, Matthew E. Kahn, Weizeng Sun, and Danglun Luo. 2014. "Incentives for China's Urban Mayors to Mitigate Pollution Externalities: The Role of the Central Government and Public Environmentalism." Regional Science and Urban Economics, 47, 61-71. 
Table 1: Summary Statistics

\begin{tabular}{|c|c|c|c|c|c|c|c|c|c|}
\hline \multirow[b]{4}{*}{ Pollution Mitigation } & \multicolumn{3}{|c|}{ Total } & \multicolumn{3}{|c|}{ Locals } & \multicolumn{3}{|c|}{ Non-locals } \\
\hline & Mean & $\begin{array}{c}\text { Standard } \\
\text { Deviation } \\
\end{array}$ & Obs & Mean & $\begin{array}{r}\text { Standard } \\
\text { Deviation }\end{array}$ & Obs & Mean & $\begin{array}{c}\text { Standard } \\
\text { Deviation } \\
\end{array}$ & Obs \\
\hline & \multicolumn{9}{|c|}{ Expenditures (100 million yuan) } \\
\hline & 117.39 & 125.37 & 341 & 129.24 & 131.25 & 134 & 109.72 & 121.12 & 207 \\
\hline $\begin{array}{l}\text { Urban Environmental } \\
\text { Infrastructure Facilities }\end{array}$ & 71.94 & 89.94 & 339 & 79.56 & 84.49 & 134 & 66.96 & 93.19 & 205 \\
\hline $\begin{array}{l}\text { Treatment of Industrial } \\
\text { Pollution Sources }\end{array}$ & 13.25 & 12.06 & 333 & 15.86 & 15.27 & 132 & 11.54 & 9.02 & 201 \\
\hline $\begin{array}{l}\text { Three-Simultaneity New } \\
\text { Construction Projects }\end{array}$ & 33.52 & 41.44 & 335 & 34.32 & 42.48 & 133 & 33 & 40.84 & 202 \\
\hline & \multicolumn{9}{|c|}{ Pollution (10k ton) } \\
\hline $\mathrm{SO} 2$ Emission & 73.66 & 46.23 & 341 & 70.43 & 49.31 & 134 & 75.75 & 44.12 & 207 \\
\hline Soot and Dust Emission & 51.61 & 38.16 & 341 & 48.62 & 35.8 & 134 & 53.54 & 39.58 & 207 \\
\hline COD & 14.58 & 11.96 & 341 & 14.47 & 11.93 & 134 & 14.65 & 12.01 & 207 \\
\hline $\mathrm{NH} 4+-\mathrm{N}$ & 1.13 & 1.00 & 332 & 1.05 & 0.92 & 134 & 1.18 & 1.05 & 201 \\
\hline & \multicolumn{9}{|c|}{ Other Variables } \\
\hline Environmental Petitions & 16493.98 & 19019.36 & 341 & 17545.01 & 18417.3 & 134 & 15813.6 & 19412.89 & 207 \\
\hline Population (10k persons) & 4244.40 & 2692.43 & 341 & 4264.4 & 2682.08 & 134 & 4231.46 & 2705.53 & 207 \\
\hline Real GDP (100 million) & 8581.87 & 8008.94 & 341 & 9135.35 & 8521.02 & 134 & 8223.58 & 7659.07 & 207 \\
\hline $\begin{array}{l}\text { Gross Regional Product } \\
\text { by Secondary Industry } \\
\text { (100 million) }\end{array}$ & 4665.44 & 4580.57 & 341 & 4968.45 & 5127.95 & 134 & 4469.28 & 4189.75 & 207 \\
\hline Deficits (million yuan) & 6.46 & 4.81 & 341 & 6.04 & 4.72 & 134 & 6.73 & 4.85 & 207 \\
\hline Social group & 6977.88 & 4594.26 & 341 & 7406.65 & 5179.01 & 134 & 6700.31 & 4162.09 & 207 \\
\hline
\end{tabular}

Table 2: First Stage Regression (Petitions and Social Group)

\begin{tabular}{|c|c|c|}
\hline \multicolumn{3}{|c|}{ Dependent variable: Petition $(\mathrm{t})$} \\
\hline Social Group & $\begin{array}{c}-2.29^{* *} \\
(1.11)\end{array}$ & $\begin{array}{c}-1.57 * * \\
(0.73)\end{array}$ \\
\hline Control variables & no & yes \\
\hline Province fixed effects & yes & yes \\
\hline Year fixed effects & yes & yes \\
\hline R square & 0.0043 & 0.016 \\
\hline Number of observations & 341 & 341 \\
\hline
\end{tabular}

Table 3: The Effect of Petition on Investment in Environmental Pollution Mitigation

\begin{tabular}{lcccc}
\hline \hline & $\begin{array}{c}\text { Environmenta } \\
\text { 1 Pollution }\end{array}$ & $\begin{array}{c}\text { Urban } \\
\text { Environmental } \\
\text { Infrastructure } \\
\text { facilities }\end{array}$ & $\begin{array}{c}\text { Treatment of } \\
\text { Industrial } \\
\text { Pollution Sources }\end{array}$ & $\begin{array}{c}\text { Environment } \\
\text { Components for Three- } \\
\text { Simultaneity New } \\
\text { Construction Projects }\end{array}$ \\
\hline Petition(t) & $0.0028^{* *}$ & $0.0029^{* *}$ & $-0.0001^{*}$ & -0.00003 \\
Petition(t-1) & $(0.001)$ & $(0.0013)$ & $(0.00005)$ & $(0.0002)$ \\
& 0.0026 & $0.0027^{* *}$ & $-6.46 \mathrm{e}-06$ & -0.0002 \\
Deficit(t-1) & $(0.0017)$ & $(0.0014)$ & $(0.00003)$ & $(0.0003)$ \\
& $-13.11^{*}$ & -11.65 & 0.14 & -3.09 \\
Population(t) & $(7.95)$ & $(8.86)$ & $(0.51)$ & $(2.27)$ \\
& -201.18 & -164.64 & $-30.88^{*}$ & -88.29 \\
log(GDP) & $(341.35)$ & $(344.59)$ & $(16.86)$ & $(80.35)$ \\
& $-706.11^{*}$ & $-647.796^{*}$ & 17.74 & 48.88 \\
Gross regional product by & $(381.83)$ & $(347.38)$ & $(29.78)$ & $(197.86)$ \\
secondary industry(t) & $0.051^{* * *}$ & $0.037^{* * *}$ & $-0.001 *$ & $0.013^{* * *}$ \\
\hline Province fixed effects & $(0.011)$ & $(0.01)$ & $(0.0004)$ & $(0.002)$ \\
Year fixed effects & yes & yes & yes & yes \\
\hline Number of observations & yes & yes & yes & yes \\
\hline
\end{tabular}




\begin{tabular}{lcccc} 
Number of provinces & 31 & 31 & 31 & 31 \\
\hline Wald test & $759.52(0.00)$ & $651.68(0.00)$ & $92.46(0.00)$ & $579.56(0.00)$ \\
Hansen test & $10.77(0.99)$ & $14.37(0.989)$ & $22.07(0.077)$ & $19.57(0.144)$ \\
Second Order test & $-1.50(0.133)$ & $-0.11(0.910)$ & $-0.06(0.950)$ & $-1.47(0.141)$ \\
\hline
\end{tabular}

Note: Control variables include GDP per capita, gross regional product by secondary industry, total population and lagged provincial deficit. Robust standard errors are in parentheses.

** Significance at 5 percent level. * Significance at 10 percent level

Table 4: The Effect of Petition on Environmental Pollution

\begin{tabular}{|c|c|c|c|c|c|c|c|c|}
\hline \multirow[b]{2}{*}{ Petition(t) } & \multicolumn{2}{|c|}{$\begin{array}{l}\text { Volume of Sulfur } \\
\text { Dioxide Emission } \\
\text { per billion GDP }\end{array}$} & \multicolumn{2}{|c|}{$\begin{array}{l}\text { Volume of Soot and } \\
\text { Dust Emission per } \\
\text { billion GDP }\end{array}$} & \multicolumn{2}{|c|}{$\begin{array}{l}\text { Volume of Industrial } \\
\text { COD Discharged per } \\
\text { billion GDP }\end{array}$} & \multicolumn{2}{|c|}{$\begin{array}{l}\text { Volume of industrial } \\
\text { Ammonia Nitrogen } \\
\text { Discharged per billion } \\
\text { GDP }\end{array}$} \\
\hline & $\begin{array}{l}-0.03 \\
(0.05)\end{array}$ & $\begin{array}{l}-0.03 \\
(0.04)\end{array}$ & $\begin{array}{l}-0.02 \\
(0.03)\end{array}$ & $\begin{array}{l}-0.02 \\
(0.04)\end{array}$ & $\begin{array}{l}-0.004 \\
(0.01)\end{array}$ & $\begin{array}{l}-0.005 \\
(0.008)\end{array}$ & $\begin{array}{l}0.00004 \\
(0.001)\end{array}$ & $\begin{array}{c}0.001 \\
(0.001)\end{array}$ \\
\hline Petition(t-1) & $\begin{array}{r}-0.001 \\
(0.03)\end{array}$ & $\begin{array}{c}0.004 \\
(0.006)\end{array}$ & $\begin{array}{r}-0.007 \\
(0.02)\end{array}$ & $\begin{array}{l}0.0004 \\
(0.005)\end{array}$ & $\begin{array}{l}-0.0001 \\
(0.006)\end{array}$ & $\begin{array}{l}0.0004 \\
(0.001)\end{array}$ & $\begin{array}{l}-0.0003 \\
(0.0005)\end{array}$ & $\begin{array}{l}-0.0002 \\
(0.0002)\end{array}$ \\
\hline Control variables & no & yes & yes & yes & no & yes & no & yes \\
\hline $\begin{array}{l}\text { Province fixed } \\
\text { effects }\end{array}$ & yes & yes & yes & yes & yes & yes & yes & yes \\
\hline Year fixed effects & yes & yes & yes & yes & yes & yes & yes & yes \\
\hline $\begin{array}{l}\text { Number of } \\
\text { observations }\end{array}$ & 310 & 310 & 310 & 310 & 310 & 310 & 301 & 301 \\
\hline Number of provinces & 31 & 31 & 31 & 31 & 31 & 31 & 31 & 31 \\
\hline R Square & 0.18 & 0.84 & 0.34 & 0.82 & 0.11 & 0.78 & 0.20 & 0.48 \\
\hline
\end{tabular}

Note: Control variables include GDP per capita, gross regional product by secondary industry and total population. Robust standard errors are in parentheses.

Table 5: Probit Regressions Estimating the Effect of (per thousand) Petitions on Political Turnover

\begin{tabular}{lcccccc} 
& \multicolumn{3}{c}{ Termination } & \multicolumn{3}{c}{ Promotion } \\
\cline { 2 - 7 } Petition(t) & $(1)$ & $(2)$ & $(3)$ & $(1)$ & $(2)$ & $(3)$ \\
& 0.03 & $0.06^{* *}$ & 0.007 & 0.002 & 0.0001 & 0.002 \\
Petition(t-1) & $(0.003)$ & $(0.003)$ & $(0.005)$ & $(0.003)$ & $(0.002)$ & $(0.002)$ \\
& $0.01^{* * *}$ & $0.01 * * *$ & $0.01^{* *}$ & $-0.009^{* * *}$ & -0.005 & -0.003 \\
age & $(0.005)$ & $(0.005)$ & $(0.08)$ & $(0.003)$ & $(0.003)$ & $(0.003)$ \\
& $0.21^{* * *}$ & $0.21^{* * *}$ & $0.36^{* * *}$ & $-0.06^{* *}$ & $-0.05^{* *}$ & $-0.09^{* * *}$ \\
education & $(0.05)$ & $(0.05)$ & $(0.08)$ & $(0.02)$ & $(0.02)$ & $(0.02)$ \\
& -0.15 & -0.15 & -0.03 & 0.13 & 0.13 & -0.03 \\
loggdp & $(0.24)$ & $(0.24)$ & $(0.44)$ & $(0.20)$ & $(0.20)$ & $(0.24)$ \\
& $-1.01^{* * *}$ & $-1.02^{* * *}$ & -2.30 & $0.70^{* * *}$ & $0.62^{* * *}$ & 0.77 \\
Constant & $(0.31)$ & $(0.30)$ & $(7.55)$ & $(0.19)$ & $(0.18)$ & $(4.31)$ \\
& -1.44 & -0.18 & 3.35 & $-6.96^{* * *}$ & $-4.47 * *$ & -3.28 \\
& $(4.22)$ & $(4.13)$ & $(77.07)$ & $(2.31)$ & $(2.19)$ & $(43.63)$ \\
\hline Province fixed effects & No & No & Yes & No & No & Yes \\
Year fixed effects & Yes & No & No & Yes & No & No \\
Province Specific Time Trend & No & Yes & Yes & No & Yes & Yes \\
\hline Number of observations & 651 & 651 & 651 & 651 & 651 & 651 \\
Log pseudolikelihood & -285.26 & -290.72 & -203.57 & -395.61 & -415.57 & -359.89 \\
\hline Note: Robust standard & & & & & &
\end{tabular}

Note: Robust standard errors are in parentheses.

*** Significance at 1 percent level. ** Significance at 5 percent level. * Significance at 10 percent level.

Table 6: The Signaling Effect of Petitions

\begin{tabular}{lcccc}
\hline \hline & $\begin{array}{c}\text { Environmental } \\
\text { Pollution }\end{array}$ & $\begin{array}{c}\text { Urban Environmental } \\
\text { Infrastructure facilities }\end{array}$ & $\begin{array}{c}\text { Treatment of Industrial } \\
\text { Pollution Sources }\end{array}$ & $\begin{array}{c}\text { Environment } \\
\text { Components for Three- } \\
\text { Simultaneity New } \\
\text { Construction Projects }\end{array}$ \\
\cline { 2 - 5 } Petition(t) & $0.005^{* * *}$ & $0.005^{* * *}$ & -0.0001 & 0.0001 \\
Locals & $(0.002)$ & $(0.002)$ & $(0.00005)$ & $(0.0003)$ \\
& $42.56^{* *}$ & $43.28^{* *}$ & 0.81 & 2.72 \\
Locals* Petition & $(19.35)$ & $(20.31)$ & $(1.53)$ & $-0.11)$ \\
& $-0.004^{* * *}$ & $-0.004^{* * *}$ & $(0.0001)$ & -0.0003 \\
\hline Control variables & $(0.001)$ & $(0.001)$ & yes & yen \\
Province fixed effects & yes & yes & yes & yes \\
Year fixed effects & yes & yes & yes & yes \\
\hline
\end{tabular}




\begin{tabular}{|c|c|c|c|c|c|c|c|c|}
\hline $\begin{array}{l}\text { Number of } \\
\text { observations }\end{array}$ & \multicolumn{2}{|c|}{279} & \multicolumn{2}{|c|}{273} & \multicolumn{2}{|c|}{271} & \multicolumn{2}{|c|}{271} \\
\hline Number of provinces & \multicolumn{2}{|c|}{31} & \multicolumn{2}{|c|}{31} & \multicolumn{2}{|c|}{31} & \multicolumn{2}{|c|}{31} \\
\hline Wald test & \multicolumn{2}{|c|}{$828.86(0.00)$} & \multicolumn{2}{|c|}{$408.35(0.00)$} & \multicolumn{2}{|c|}{$193.18(0.00)$} & \multicolumn{2}{|c|}{$801.16(0.00)$} \\
\hline Hansen test & \multicolumn{2}{|c|}{$11.84(0.961)$} & \multicolumn{2}{|c|}{$12.21(0.953)$} & \multicolumn{2}{|c|}{$15.78(0.827)$} & \multicolumn{2}{|c|}{$20.29(0.565)$} \\
\hline Second Order test & \multicolumn{2}{|c|}{$-1.49(0.136)$} & \multicolumn{2}{|c|}{$-0.51(0.610)$} & \multicolumn{2}{|c|}{$-0.14(0.890)$} & \multicolumn{2}{|c|}{$-1.33(0.182)$} \\
\hline \multicolumn{9}{|c|}{ Test of general linear restriction } \\
\hline & Locals & Nonlocals & Locals & Nonlocals & Locals & Nonlocals & Locals & Nonlocals \\
\hline & 0.0009 & $0.005 * * *$ & 0.001 & $0.005 * * *$ & -0.0001 & -0.0001 & -0.0002 & 0.0001 \\
\hline & $(0.0007)$ & $(0.002)$ & $(0.001)$ & $(0.002)$ & $(0.0001)$ & $(0.00005)$ & $(0.0001)$ & $(0.0003)$ \\
\hline
\end{tabular}

Note: Control variables include GDP per capita, gross regional product by secondary industry, total population and lagged provincial deficit. Robust standard errors are in parentheses.

*** Significance at 1 percent level. ** Significance at 5 percent level.

Figure 1: Distribution of Letters and Visits

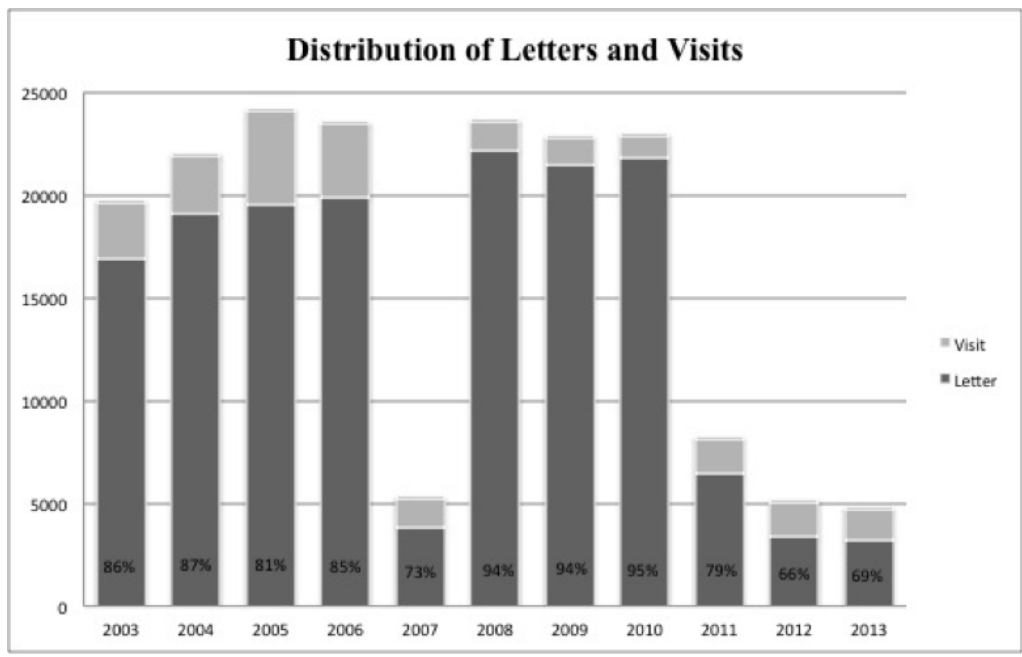

Note: The values in the bar show the percentage of petitions via letters each year. The data are from various issues of the China Environmental Statistics and are calculated by the authors.

Figure 2: Distribution of Petitions across Provinces

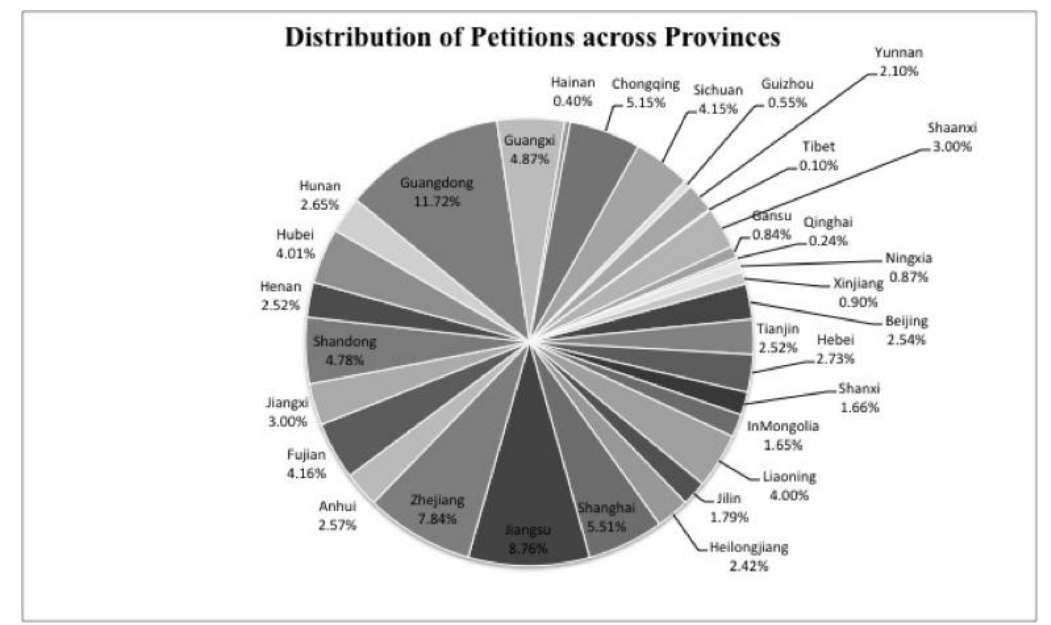

Note: The data are from various issues of the China Environmental Statistics and are calculated by the authors. 